\title{
Environmental use of HCFA: oil soil clean up
}

\author{
A. Moutsatsou, C. Drosou, N. Giannakeas \& O. K. Karakasi \\ Department of Chemical Engineering, \\ National Technical University of Athens, Greece
}

\begin{abstract}
The present study focuses on the evaluation of high calcium fly ash (HCFA), an inorganic waste material produced by electric power plants in large quantities. Properties of HCFA, such as mineralogical and chemical composition, fine particle size, porosity, floating ability and hydrophobicity makes its application in oil spill clean-up attractive. Its sorption capacity depends on its composition and the oil type. Its floating ability has a better result in thin oil spill layers, specifically its coarse fraction, which seems to outmatch due to its higher $\mathrm{Si}$ content. Hydrothermal treatment with $\mathrm{NaOH}$ solution, with or without a template (tetrapropylammonium bromide), despite the increase in porosity and the decrease in specific gravity, has rather reduced the hydrophobic character and therefore its affinity for oil. The change in $\mathrm{Si} / \mathrm{Al}$ content by the addition of $\mathrm{SiO}_{2}$ has proved to ameliorate its sorption capacity, but not its floating ability. The application of a HCFA-oil mixture as road construction material seems to be encouraging. It contributes to the elimination of dust production during the paving of a road with gravel, and ameliorates the soil strength, which encourages its application in soil stabilisation.
\end{abstract}

Keywords: high calcium fly ash, sorbent, oil spill, tetrapropylammonium bromide, soil stabilisation, road construction.

\section{Introduction}

Pollution of the sea caused both by oil spilled accidentally and by routine ship operations is an environmental issue of great importance, requiring immediate action for its confrontation and prevention. To this direction several oil spill cleanup techniques have been developed, such as the use of booms and skimmers, oil pumping [6], in situ burning, bioremediation [9], the use of chemical agents such as dispersants [12], solidifiers and sorbents. The use of sorbents in particular is of 
great interest, as it offers the possibility of collection and complete removal of oil, by achieving a change from liquid to semi-solid phase [1].

The efficiency of an oil sorbent material is determined by properties such as hydrophobicity, oleophilicity, high uptake capacity, high rate of uptake, retention over time, oil recovery, reusability and biodegradability [4]. The sorbent materials used for oil spill clean-up can be classified as synthetic organic, natural organic and inorganic mineral products. As inorganic oil sorbents, $\mathrm{CF}_{3}$-modified silica aerogels [17], pure- or high-silica synthetic zeolites and geopolymers, organophilic clays [1], exfoliated graphite [21], expanded perlite [18] and activated carbon [1] have been examined.

The use of inorganic mineral products as sorbents of oil, or in general organic compounds, presupposes in most cases their chemical or surface modification, in order to improve their hydrophobicity and therefore their affinity for organic compounds. For example, $\mathrm{CF}_{3}-(\mathrm{CH})_{2}$ - modified silica aerogels have an excellent oil sorption capacity [17]. Quartenary ammonium cations ameliorate the affinity of clays for organic compounds, such as phenols [10] and pesticides [19]. For the improvement of the hydrophobic character of zeolites several techniques have been developed, such as the production of pure- or high-silica zeolites, by using a highsilica source and an organic template, in most cases quartenary ammonium salts [2, $7,8]$, or the dealumination [15]. The use of hydrophobic zeolites has been successfully investigated for the sorption of volatile organic compounds [13].

The present study aims at the evaluation of high calcium fly ash by application as an inorganic oil sorbent material. HCFA is a by-product of combustion of lignite in electric power plants, produced in huge quantities. Approximately 500 million tones of coal fly ash are annually produced worldwide and 12 million tones of lignite fly ash respectively in Greece $[5,11]$. In order to eliminate the amount of fly ash landfilled, research is focusing on the development of new environmental applications, such as waste stabilisation and solidification, water environmental improvement [20] and zeolite synthesis [16]. Particularly in Greece only $20 \%$ of lignite fly ash is used in construction applications, the other being landfilled. However, lignite fly ash is characterised by fine particle size, floating ability, hydrophobicity and porosity, properties, which can be proved useful for its application as an oil sorbent material. The oil sorption behaviour of HCFA is investigated, taking into account its chemical and mineralogical composition, its particle size, the oil type and the oil spill layer. The effect of its hydrothermal treatment with $\mathrm{NaOH}$ aqueous solution, with or without a template (tetrapropylammonium bromide), with or without modification of the $\mathrm{Si} / \mathrm{Al}$ ratio, on its oil sorption capacity and its affinity for oil is also examined. Furthermore the application of the HCFA-oil mixture as a road construction material is investigated.

\section{Materials and methods}

\subsection{HCFA samples}

Two samples of high calcium lignite fly ash (HCFA), AD and M, have been examined, originated from electric power plants in Greece (Ptolemais area, 
Megalopolis area respectively), differing in chemical and mineralogical composition, as it is shown in table 1. For the characterisation of fly ashes measurements of $\mathrm{pH}$ (ISO 6588), chlorides content (EN 196-21), specific gravity (ASTM C642-90), particle size distribution (DIN 4188) and specific surface area have been performed. Furthermore, X-Ray Diffraction Analysis (Siemens D500), Thermogravimetric Analysis (Mettler TGA/STDA 851 ${ }^{\mathrm{C}}$ ) and Scanning Electron Microscopy (SEM) defined the structure of the ashes.

Table 1: $\quad$ Chemical and mineralogical analysis of HCFA samples.

\begin{tabular}{|c|c|c|}
\hline $\mathbf{\%}(\mathbf{w} / \mathbf{w})$ & $\mathbf{A D}$ & $\mathbf{M}$ \\
\hline $\mathrm{SiO}_{2}$ & 29.73 & 51.26 \\
\hline $\mathrm{Al}_{2} \mathrm{O}_{3}$ & 13.90 & 19.39 \\
\hline $\mathrm{Fe}_{2} \mathrm{O}_{3}$ & 6.49 & 8.44 \\
\hline $\mathrm{CaO}$ & 34.13 & 11.82 \\
\hline $\mathrm{MgO}$ & 3.56 & 2.27 \\
\hline $\mathrm{SO}_{3}$ & 5.13 & 2.91 \\
\hline $\mathrm{Na}_{2} \mathrm{O}$ & 1.12 & 0.53 \\
\hline $\mathrm{K}_{2} \mathrm{O}$ & 0.68 & 1.81 \\
\hline L.O.I. & 4.03 & 1.67 \\
\hline
\end{tabular}

\begin{tabular}{|c|c|c|}
\hline mineral & AD & M \\
\hline $\mathrm{SiO}_{2}$ Quartz & + & + \\
\hline $\mathrm{CaSO}{ }_{4}$ Anhydrite & + & + \\
\hline $\mathrm{CaO}$ Lime & + & + \\
\hline $\mathrm{Ca}(\mathrm{OH})_{2}$ Portlandite & + & - \\
\hline$(\mathrm{Na}, \mathrm{Ca}) \mathrm{AlSi}_{3} \mathrm{O}_{8}$ Feldspars & + & + \\
\hline $\mathrm{Ca}_{2} \mathrm{Al}\left(\mathrm{Al}, \mathrm{Si}_{2} \mathrm{O}_{8}\right.$ Gehlenite & + & - \\
\hline $\mathrm{CaAl}_{2} \mathrm{Si}_{2} \mathrm{O}_{8} \cdot 4 \mathrm{H}_{2} \mathrm{O}_{\mathrm{Gismodine}}$ & + & - \\
\hline $\mathrm{MgO}_{2} \mathrm{Al}_{2} \mathrm{O}_{3} \mathrm{SiO}_{2}$ & - & + \\
\hline $\mathrm{K}_{2} \mathrm{SO}_{4} \cdot \mathrm{XH}_{2} \mathrm{O}$ & - & + \\
\hline $\mathrm{Ca}_{3} \mathrm{Mg}_{2}\left(\mathrm{SiO}_{4}\right)_{2}$ & + & - \\
\hline
\end{tabular}

Table 2: $\quad$ Properties of heating oil (HO), light cycle oil (LCO) and Iranian light crude oil (ILCO).

\begin{tabular}{|c|c|c|c|}
\hline Parameters & HO & LCO & ILCO \\
\hline $\begin{array}{c}\text { Density }\left(\mathrm{g} / \mathrm{cm}^{3}\right)\left(22^{\circ} \mathrm{C}\right) \\
\text { ASTM D1298 }\end{array}$ & 0.8216 & 0.8173 & 0.8669 \\
\hline $\begin{array}{c}\text { Viscosity }(\mathrm{cSt})\left(22^{\circ} \mathrm{C}\right) \\
\text { ASTM D445 }\end{array}$ & 3.2689 & 4.6979 & 13.84 \\
SVM 3000 STABINGER VISCOMETER & & & \\
\hline S Content $(\% \mathrm{w} / \mathrm{w})$ & 0.155 & 2.05 & 1.93 \\
\hline
\end{tabular}

\subsection{Oil sorption behaviour of non-modified and modified HCFA}

For the evaluation of the oil sorption behaviour of the HCFA, oil spill has been simulated by using artificial ocean-water, prepared according to ASTM D114190, and three different types of oil, heating oil (HO), light cycle oil (LCO), Iranian light crude oil (ILCO), have been used, in order to simulate all cases of transportations. Their physicochemical characteristics are shown in table 2 . Amounts of oil, 20,10,4mL, were added to $150 \mathrm{~mL}$ of artificial ocean-water, in order to investigate the effect of the oil spill layer on the floating ability of HFCA. In order to investigate the effect of the particle size of fly ashes on the floating ability and the oil sorption capacity, two fractions (particle size $<56 \mu \mathrm{m}$ and $>56 \mu \mathrm{m}$ ) were also examined.

For the hydrothermal treatment of the samples, the effect of $\mathrm{NaOH}$ solution, of tetrapropylammonium bromide (TPA) as an organic template, of temperature, pressure, time, $\mathrm{Si} / \mathrm{Al}$ ratio was the main goal under investigation. In table 3 the conditions of the hydrothermal treatment are presented. Previous experiments of our laboratory defined the first ratio [14], while the others have been based on 
data $[3,7,8]$. Increase of $\mathrm{Si} / \mathrm{Al}$ ratio was achieved by adding sand to the samples. The hydrothermal treatment at $90^{\circ} \mathrm{C}$ took place in atmospheric pressure and that of $150^{\circ} \mathrm{C}$ in an autoclave. The products of hydrothermal treatment were collected by filtration, washed with deionised water and dried at $90^{\circ} \mathrm{C}$ for 1 day. Their mineralogical composition was defined by X-Ray Diffraction Analysis and their porosity and specific surface area were measured by $\mathrm{N}_{2}$-adsorption (NOVA-2200 Ver. 6.11).

For the evaluation of the oil sorption behaviour, $2 \mathrm{~mL}$ of oil were added to $150 \mathrm{~mL}$ of artificial ocean-water and mixed with $1 \mathrm{~g}$ of sample. These amounts have been selected, because the floating ability of the samples has been proved better at such a thin oil spill layer. The floating mixture was collected after 4 days, in order to achieve a more cohesive semi-solid phase, and the precipitated material was determined.

\subsection{Application of the oil-HCFA mixture as a road construction material}

Oil-HCFA mixture has been mixed with road gravel $3 \mathrm{~A}$ in different ratios, in order to investigate elimination of dust production during mixing and road paving with gravel. Ratios $2.5,5.0 \% \mathrm{w} / \mathrm{w}$ of oil-HCFA mixture and gravel were prepared and the dust production was determined by weighting a paper film, adapted to the mixing ball, before and after mixing. For the road paving process the oil-HCFA mixture was added to gravel in ratios 3.3, 5.0\% w/w and the dust production was determined by weighting a sack, in which the simulation of the road paving process took place, before and after the process.

The application of oil-HCFA mixture in soil stabilisation was also investigated. The soil was a clayey one and its particle size was determined according to AASHTO T 11-77-I, the liquid limit (LL) according to AASHTO T 89-76I, the plastic limit (PL) and the plasticity index (PI) according to AASHTO $\mathrm{T}$ 90-70, the moisture content $(\mathrm{w})$ according to AASHTO T 239-76I (ASTM D $3017-72)$, the optimum moisture content $\left(\mathrm{w}_{\mathrm{opt}}\right)$ and the maximum density $\left(\gamma_{\mathrm{d}, \max }\right)$ according to AASHTO T 99-74 and the results are shown in table $4.3 \% \mathrm{w} / \mathrm{w}$ of oil-HCFA mixture was added to the soil and compacted to cylindrical specimens of $5 \mathrm{~cm}$ diameter and of $10 \mathrm{~cm}$ height and were allowed to cure at $100 \%$ relative humidity for 7, 60 and 90 days. Their compressive strength, their liquid and plastic limit and their plasticity index were determined.

Table 3: $\quad$ Conditions of hydrothermal treatment of HCFA.

\begin{tabular}{|c|c|c|c|c|c|c|}
\hline \multirow[t]{2}{*}{ ratio (mol) } & \multirow{2}{*}{$\begin{array}{c}\mathrm{C}_{\mathrm{NaOH}} \\
\text { (M) }\end{array}$} & \multirow{2}{*}{$\begin{array}{l}\text { mL sol./ } \\
\text { g HCFA }\end{array}$} & \multicolumn{2}{|c|}{$\mathrm{SiO}_{2} / \mathrm{Al}_{2} \mathrm{O}_{3}$} & \multirow{2}{*}{$\begin{array}{c}\mathrm{T} \\
\left({ }^{\circ} \mathrm{C}\right)\end{array}$} & \multirow[t]{2}{*}{ t (d) } \\
\hline & & & AD & M & & \\
\hline & 1 & 20 & \multirow{7}{*}{3.6} & \multirow{7}{*}{4.5} & 90 & 1 \\
\hline $1 \mathrm{SiO}_{2}: 0.3 \mathrm{TPA}: 40 \mathrm{H}_{2} \mathrm{O}$ & & & & & 90 & 1 \\
\hline $1 \mathrm{SiO}_{2}: 0.2 \mathrm{TPA}: 0.2 \mathrm{NaOH}: 40 \mathrm{H}_{2} \mathrm{O}$ & & & & & 90 & 1 \\
\hline $1 \mathrm{SiO}_{2}: 0.2 \mathrm{TPA}: 0.2 \mathrm{NaOH}: 40 \mathrm{H}_{2} \mathrm{O}$ & & & & & 90 & 7 \\
\hline $1 \mathrm{SiO}_{2}: 0.2 \mathrm{TPA}: 0.2 \mathrm{NaOH}: 40 \mathrm{H}_{2} \mathrm{O}$ & & & & & 90 & 14 \\
\hline $1 \mathrm{SiO}_{2}: 0.5 \mathrm{TPA}: 0.2 \mathrm{NaOH}: 40 \mathrm{H}_{2} \mathrm{O}$ & & & & & 90 & 30 \\
\hline $1 \mathrm{SiO}_{2}: 0.2 \mathrm{TPA}: 0.2 \mathrm{NaOH}: 40 \mathrm{H}_{2} \mathrm{O}$ & & & & & 150 & 7 \\
\hline $1 \mathrm{SiO}_{2}: 0.2 \mathrm{TPA}: 0.2 \mathrm{NaOH}: 40 \mathrm{H}_{2} \mathrm{O}$ & & & \multicolumn{2}{|c|}{68} & 150 & 7 \\
\hline $1 \mathrm{SiO}_{2}: 0.2 \mathrm{TPA}: 0.5 \mathrm{NaOH}: 40 \mathrm{H}_{2} \mathrm{O}$ & & & \multicolumn{2}{|c|}{40} & 150 & 7 \\
\hline
\end{tabular}


Table 4: $\quad$ Soil properties.

\begin{tabular}{|c|c|}
\hline Parameter & Soil \\
\hline fines $(<0.075 \mathrm{~mm})(\%)$ & 77.0 \\
\hline $\mathrm{LL}(\%)$ & 32.0 \\
\hline PL $(\%)$ & 22.5 \\
\hline $\mathrm{PI}(\%)$ & 9.5 \\
\hline $\mathrm{W}(\%)$ & 14.8 \\
\hline $\mathrm{w}_{\text {opt }}(\%)$ & 16.6 \\
\hline$\gamma_{\mathrm{d}, \max }\left(\mathrm{kg} / \mathrm{m}^{3}\right)$ & 1849 \\
\hline AASHTO classification & $\mathrm{A}-7-6$ \\
\hline
\end{tabular}

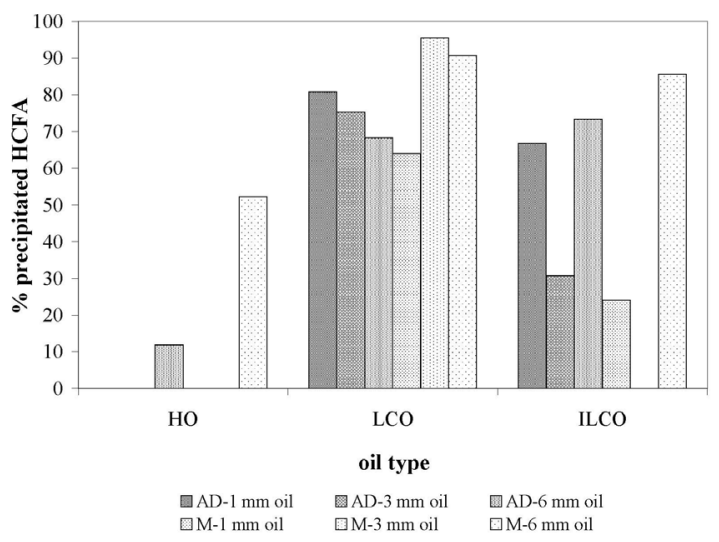

Figure 1: $\quad$ Percentage of precipitated HCFA in different oil spill layers.

\section{Results and discussion}

\subsection{Oil sorption behaviour of HCFA}

The oil sorption behaviour of HCFA has been proved encouraging. Concerning the effect of the composition of HCFA on its oil sorption behaviour, the more calcareous fly ash, AD, seems to behave better: it is retained in the oil-water interface to a greater extent and has a higher oil sorption capacity. This is due to the $\mathrm{CaO}$ and $\mathrm{Al}_{2} \mathrm{O}_{3}$ content, which leads to early settling time of the material and the adsorbed oil is retained on the surface.

Concerning the effect of oil spill layer, HCFA seems to behave better in thin oil spill layers, a factor which makes it an attractive sorbent material, as the mechanical removal is impossible in thin oil spill layers. The percent of precipitation in relation to the oil spill layer is shown in fig. 1. Further experiments have shown that HCFA behaves even better in even thinner oil spill layers. By adding $1 \mathrm{~g}$ HCFA AD to a $0.5 \mathrm{~mm}$ oil spill layer $(2 \mathrm{~mL}$ oil $)$, only HCFA granules precipitated, without sweeping down oil, as it occurs in case of wider oil spill layers, and after 4 days a semi-solid oil-HCFA phase was achieved, which allowed quite total oil removal. For this reason this ratio has been applied, in order to investigate the oil sorption behaviour of modified HCFA. 
Concerning the effect of particle size, the coarse fraction seems to behave better. This could be attributed to higher amorphous phase content of the coarse fraction of HCFA, which is rich in $\mathrm{Si}$, whose phases contribute to the hydrophobic character. Since, however, no significant differences are observed concerning the oil sorption capacity, the division of HCFA in fractions of different particle size would not be recommended.

Concerning the effect of oil type, no certain conclusions can be drawn. A semi-solid phase, when achieved, is easier to form in case of HO and ILCO, whereas in case of LCO the oil-HCFA mixture tends to precipitate.

\subsection{Oil sorption behaviour of modified HCFA}

The products of the hydrothermal treatment of HCFA have lower specific gravity and higher mean pore diameter, pore volume and specific area. The lowest specific gravity $(27 \%$ decrease in case of $\mathrm{AD}, 12 \%$ in case of $\mathrm{M})$ is achieved in case of treatment only with $\mathrm{NaOH}$ and in case of increasing the $\mathrm{Si} / \mathrm{Al}$ content. The highest values of mean pore diameter, pore volume and specific area are achieved in case of increasing the $\mathrm{Si} / \mathrm{Al}$ content. The achieved mean pore diameter is 1.5 to 3.5 times higher than the initial and the pore volume 15 to 30 times higher in case of $M$ and $A D$ respectively, and the specific area 10 to 15 times higher in case of $\mathrm{AD}$ and $\mathrm{M}$ respectively.

According to XRD-patterns the hydrothermal treatment of HCFA without changing the $\mathrm{Si} / \mathrm{Al}$ content results in case of $\mathrm{AD}$ in decrease in lime $(\mathrm{CaO})$, increase in calcite $\left(\mathrm{CaCO}_{3}\right)$, production of hibschite $\left(\mathrm{Ca}_{3} \mathrm{Al}_{2}\left(\mathrm{SiO}_{4}\right)_{1.25}(\mathrm{OH})_{7}\right)$ in presence of $\mathrm{NaOH}$, and after 14 days at $90^{\circ} \mathrm{C}$ and at $150^{\circ} \mathrm{C}$ in production of zeolite ZSM-11 ( $\left.\mathrm{H}-\mathrm{Al}_{2} \mathrm{O}_{3} \cdot \mathrm{SiO}_{2}\right)$. In case of $\mathrm{M}$ it results in production of zeolite (P1) $\mathrm{Na}\left(\mathrm{Na}_{6} \mathrm{Al}_{6} \mathrm{Si}_{10} \mathrm{O}_{32} \cdot 12 \mathrm{H}_{2} \mathrm{O}\right)$ only after 14 days at $90^{\circ} \mathrm{C}$ and at $150^{\circ} \mathrm{C}$. When changing the $\mathrm{Si} / \mathrm{Al}$ content in case of $\mathrm{M}$ a-quartz $\left(\mathrm{SiO}_{2}\right)$ and analcime phases $\left(\mathrm{NaAl}\left(\mathrm{SiO}_{3}\right)_{2} \cdot \mathrm{H}_{2} \mathrm{O}\right)$ are detected, whereas in case of $\mathrm{AD}$ a-quartz, analcime-c $\left(\mathrm{Na}\left(\mathrm{Si}_{2} \mathrm{Al}\right) \mathrm{O}_{6} \cdot \mathrm{H}_{2} \mathrm{O}\right)$, and several $\mathrm{Ca}-\mathrm{Al}-\mathrm{O}$ phases are detected.

Due to the increase in the porosity achieved by the hydrothermal treatment, the product would be expected to behave better, when added to an oil spill. However, in case of maintaining the initial $\mathrm{Si} / \mathrm{Al}$ content, the hydrophilic character of the produced zeolitic phases seems to impose. The modified products precipitate in all oil types to a greater extent than the initial HCFA. The modified products precipitate in form of granules and cannot be retained in the oil-water interface, as it occurs with the initial HCFA, which indicates a weak interaction with oil. The poor performance could also be attributed to the size of pores produced by the hydrothermal treatment, which are in the order of micropores, i.e. smaller than the oil molecules. In case of increasing the $\mathrm{Si} / \mathrm{Al}$ content, an amelioration of the oil sorption behaviour is observed in case of ILCO, in ratio $\mathrm{SiO}_{2} / \mathrm{Al}_{2} \mathrm{O}_{3}=40$ for $\mathrm{AD}$ and in ratio $\mathrm{SiO}_{2} / \mathrm{Al}_{2} \mathrm{O}_{3}=68$ for $\mathrm{M}$. This could be attributed not only to the lower specific gravity and the highest porosity achieved in these cases, but also to the hydrophobic character of the produced zeolitic phases. However, precipitation still takes place. 


\subsection{Application of oil-HCFA mixture as a road construction material}

The addition of the produced oil-HCFA mixture to road gravel $3 \mathrm{~A}$ has been proved successful in reducing the produced dust during mixing and paving. Particularly, addition of oil-HCFA mixture in a ratio $2.5-5.0 \%$ to gravel has resulted in all cases in dust reduction in the order of $20-60 \%$ during mixing. Satisfactory has been also the dust reduction achieved by addition of 3.3-5.0\% of oil-HCFA mixture to gravel during the simulation of road paving, as it is shown in fig. 2.

The results of the application of the oil-HCFA mixture in soil stabilisation are also encouraging, as it is illustrated in fig. 3. After 7 days an increase in compressive strength in the order of $20-50 \%$ is achieved for all the samples,

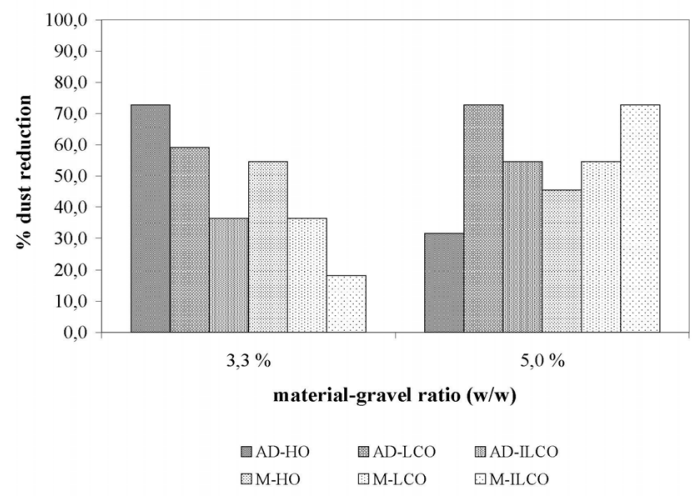

Figure 2: Percentage dust reduction in different oil-HCFA mixture/gravel ratios.

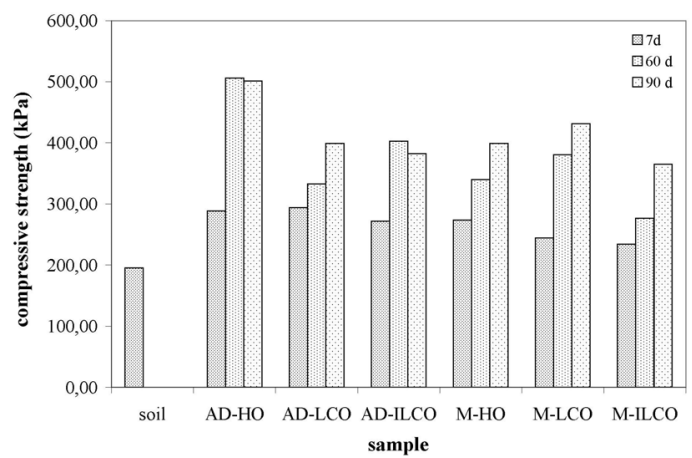

Figure 3: Compressive strength of soil and oil-HCFA-soil mixtures after 7, 60 and 90 days cure. 
compared to the soil. The results are more encouraging after 60 and 90 days, where HCFA compressive strength is developed. After 60 days the compressive strength is 1.7-2.6 times greater than this of soil in case of AD and 1.4-1.9 times greater in case of $\mathrm{M}$, while after 90 days it is 2.0-2.6 times greater in case of AD and 1.9-2.2 times greater in case of M. The more calcareous HCFA AD results in higher compressive strength, as it is expected, because of its higher $\mathrm{CaO}$ content, which is responsible for strength development.

\section{Conclusions}

High calcium fly ash is a waste material produced annually in huge quantities, whose greatest amount is landfilled. However, it exhibits properties, such as fine particle size, porosity, floating ability and hydrophobicity, which make it attractive for several applications. The goal of the present study was the use of HCFA as an oil sorbent material.

Its oil sorption behaviour seems to depend on its composition and especially on its $\mathrm{CaO}$ content. The more calcareous HCFA is better retained in the oil-water interface and has quite higher oil sorption capacity. It is able to form a semi-solid phase with oil, which can be easily removed from the water, resulting to quite total oil removal. Its behaviour is better in heating oil and crude oil, which are oil types commonly transported by sea.

In order to ameliorate it's floating ability and oil sorption capacity, hydrothermal treatment in several conditions has been applied. The use of $\mathrm{NaOH}, \mathrm{TPABr}$ and the combination of both, by maintaining the initial $\mathrm{Si} / \mathrm{Al}$ ratio, has resulted in final products with poor performance, despite the achieved decrease in specific gravity and increase in porosity. This could be attributed to the hydrophilic character of the produced zeolitic phases. Only by increasing the initial $\mathrm{Si} / \mathrm{Al}$ ratio, which leads to production of hydrophobic zeolitic phases, an amelioration of oil sorption behaviour was observed. However, in order to achieve this amelioration, a great amount of $\mathrm{SiO}_{2}$, compared to the amount of treated HCFA, should be added and an autoclave should be used, which results in a great cost increase, which is not the purpose of this study, which aims at evaluating a waste material.

The results of the application of the produced oil-HCFA mixture in road construction are encouraging. It results in a satisfactory decrease in dust production during mixing with road gravel $3 \mathrm{~A}$ and paving a road with it. Its application in soil stabilisation has resulted in an increase in compressive strength after 90 days in the order of 2.0-2.5 times, which makes it an attractive material for road subgrades.

\section{Acknowledgements}

O. K. Karakasi is supported by an A. S. Onassis Public Benefit Foundation Scholarship.

The project is co-funded by the European Social Fund (75\%) and National Resources (25\%). 


\section{References}

[1] Adebajo, M.O., Frost, R.L., Kloprogge, J.T., Carmody, O., Kokot, S., Porous materials for oil spill clean up: a review of synthesis and absorbing properties. Journal of Porous Materials, 10(3), pp. 159-170, 2003.

[2] Burkett, S.L., Davis, M.E., Mechanism of Structure Direction in the synthesis of pure-silica Zeolites. 2. Hydrophobic Hydration and Structural Specificity. Chem. Mater., 7, pp. 1453-1463, 1995.

[3] Chareonpanich, M., Namto, T., Kongkachnichay, P., Limtrakul, J., Synthesis of ZSM-5 zeolite from lignite fly ash and rice husk ash. Fuel Processing Technology, 85, pp. 1623-1634, 2004.

[4] Doerffer, J.W., Oil Spill Response in the Marine Environment. Pergamon Press, 1992.

[5] Georgakopoulos, A., Filippidis, A., Kassoli-Fournaraki, A., Iordanidis, A., Fernández-Turiel, J.L., Llorens, J.F., Gimeno, D., Environmentally important elements in fly ashes and their leachates of power stations of Greece. Energy Sources, 24, pp. 83-91, 2002a.

[6] Ghannam, M.T., Chaalal, O., Oil spill cleanup using vacuum technique. Fuel, 82, pp. 789-797, 2003.

[7] Gittleman, C.S., Lee, S.S., Bell, A.T., Radke, C.J., Zeolite synthesis from tetralkylammonium silicate gels. Microporous Materials, 3, pp. 511-530, 1995.

[8] Goretsky, A.V., Beck, L.W., Zones, S.I., Davis, M.E., Influence of the hydrophobic character of structure-directing agents for the synthesis of pure-silica zeolites. Microporous and Mesoporous Materials, 28, pp. 387 393, 1999.

[9] Hoff, R.Z., Bioremediation: An Overview of its Development and Use for Oil Spill Cleanup. Marine Pollution Bulletin, 26, 476, 1993.

[10] Jiang, J.-Q., Zeng, Z., Comparison of modified montmorillonite adsorbents, Part II: The effects of the type of raw clays and modification conditions on the adsorption performance. Chemosphere, 53, pp. 53-62, 2003.

[11] Kolovos, N., Georgakopoulos, A., Filippidis, A., Kavouridis, C., Utilization of lignite reserves and simultaneous improvement of dust emissions and operation efficiency of a power plant by controlling the calcium (total and free) content of the fed lignite. Application on the Agios Dimitrios power plant, Ptolemais, Greece. Energy and Fuels, 16, pp. 1516-1522, 2002.

[12] Lessard, R.R., Demarco, G., The Significance of Oil Spill Dispersants. Spill Science \& Technology Bulletin, 6(1), pp. 59-68, 2000.

[13] Meininghaus, C.K.W., Prins, R., Sorption of volatile organic compounds on hydrophobic zeolites. Microporous and Mesoporous Materials, 35-36, pp. 349-365, 2000.

[14] Moutsatsou, A., Gregou M., Matsas, D., Protonotarios, V., Washing as a remediation technology applicable in soils heavily polluted by miningmetallurgical activities. Chemosphere, 63(10), pp. 1632-1640, 2006.

[15] Otten, W., Gail, E., Frey, T., Einsatzmöglichkeiten hydrophober Zeolithe in der Adsorptionstechnik. Chem.-Ing.-Tech., 64, pp. 915-925, 1992. 
[16] Querol, X., Moreno, N., Umanã, J.C., Alastuey, A., Hernández, E., LópezSoler, A. Plana, F., Synthesis of zeolites from coal fly ash: an overview. International Journal of Coal Geology, 50, pp. 413-423, 2002.

[17] Reynolds, J.G., Coronado, P.R., Hrubesh, L.W., Hydrophobic aerogels for oil spill clean up-synthesis and characterisation. Journal of Non-Crystalline Solids, 292, pp. 127-137, 2001.

[18] Roulia, M., Chassapis, K., Fotinopoulos, Ch., Savvidis, Th., Katakis, D., Dispersion and Sorption of Oil Spills by Emulsifier-Modified Expanded Perlite. Spill Science \& Technology Bulletin, 8(5-6), pp. 425-431, 2003.

[19] Sanchez-Martin, M.J., Rodriguez-Cruz, M.S., Andrades, M.S. SanchezCamazano, M., Efficiency of different clay minerals modified with a cationic surfactant in the adsorption of pesticides: Influence of clay type and pesticide hydrophobicity. Applied Clay-Science, (available on line), 2005.

[20] Scheetz, B.E., Earle, R., Utilization of fly ash. Current Opinion in Solid State \& Materials Science, 3, pp. 510-520, 1998.

[21] Toyoda, M., Aizawa, J., Inagaki, M., Sorption and recovery of heavy oil by using exfoliated graphite. Desalination, 115, pp. 199-201, 1998. 